\title{
The Power of the Illegitimate
}

\section{La Divina Pastora and the "Coolie Mission" in Colonial Trinidad}

\author{
Teruyuki Tsuji \\ Hiroshima University, Hiroshima, Japan \\ caribjap@gmail.com
}

\begin{abstract}
Based on archival research and supplemented by ethnographic observations, this article critically revisits the history of La Divina Pastora, the Madonna of Spanish origin, in colonial Trinidad, focusing on how the spirituality and materiality of two statues of this Marian image intersected, competed, and reinforced each other: a fair-complexioned La Divina Pastora in northern Trinidad, created and patronized by the Catholic central authorities; and a dark-skinned, miracle-working La Divin/Sipari Mai in Siparia, formerly a peripheral Spanish mission in southern Trinidad. Tracing the trajectory of their lives and relations reveals the complexities of the ecclesiastical history of Trinidad, unearthing the contradictions and tensions between the patriarchal making and remaking of religious orthodoxy and the popular praxis of faith for day-to-day substantive issues needing medico-spiritual solutions. Unlike extant studies, addressing the two distinct statues representing the same Marian image, this article utilizes a holistic approach in order to appreciate why and how the Madonna at Siparia emerged, survived, and thrived as a shared empowering object, despite the colonial obsession with racial-cultural purity and regimes of the boundaries of belonging. The conflicts among the Christian communities were intertwined and thwarted the Catholic central authority's attempts to exploit La Divin/Sipari Mai's transgressive power to attract Hindus to the Church. The tangled conflicts also created conditions in which Hindu supplications for miraculous cures persisted and thrived, despite discrimination and repression by the Catholic authorities. The incessant interactions between Catholics and Hindu devotees in Siparia led to the combination of their originally divergent practices and worldviews and the transformation of the dark-colored Madonna from La Divina Pastora to La Divin/Sipari Mai, an alternative spiritual construction that represented various maternal/female bodies, each conforming to distinct religious traditions.
\end{abstract}




\section{Keywords}

La Divina Pastora - Virgin Mary - Christian mission - Hinduism - Trinidad

\section{Introduction}

Among the chattels of late Fr. John Pius Dowling, the former Roman Catholic archbishop of Port-of-Spain, Trinidad, is a photograph of a statue of a crowned, fair-skinned lady with a shepherd's crook sitting with the infant Jesus on her lap and the lamb at her feet (see Figure 1). On the back of the photograph, written in Portuguese, is "Image of Our Lady, honored under the title of 'La Divina Pastora' in the mother church of Arouca (Imagem de Nossa Senhora, honrada debaixo do título de 'La Divina Pastora' na igreja matriz de Arouca)." Arouca is a Catholic parish in northern central Trinidad, which began life as a Capuchin Franciscan mission for the indigenous population in the seventeenth century. ${ }^{1}$ The title La Divina Pastora (The Divine Shepherdess) came from the mythical origin of this Marian image: in 1703, the Virgin Mary allegedly appeared in a vision to Capuchin friar Isidoro de Sevilla in Andalucía, Spain. In the vision, Mary was dressed like a shepherdess and prompted him to spread the Gospel (Alcaraz 1831; Carrocera 1968).

In Trinidad today, the La Divina Pastora in the photograph is virtually unknown, even among Catholics. However, there is another La Divina Pastora in this former British colony, a dark-complexioned lady lacking the identity symbols of the Divine Shepherdess, baby Jesus, and the lamb (see Figure 2), ${ }^{2}$ who is renowned for her miraculous cures and who draws the faithful to her shrine in the southern Catholic parish of Siparia (Anthony 20o1; Rétout 1976). ${ }^{3}$

1 Anthony 2001 and Rétout 1976. The statue of La Divina Pastora, which today is cared for by Catholics in Lopinot, a pastoral district of Arouca, is distinct from the Madonna in the picture. More research is needed if we are to further understand the history of La Divina Pastora in Trinidad.

2 One of the stories circulating is that the Madonna at Siparia once bore these identity icons, but they were stolen. This view was reiterated by an archbishop-commissioned archivist, who was critical of the decision to accommodate Hindu pilgrims with the Madonna at Siparia (focus group interview, June 12, 2016). However, there is no written evidence to support this claim. Since the late nineteenth century, newspapers have often reported that the Madonna's valuable accessories, donated by the faithful, had been carried away, but none of them referred to the identity icons (e.g., Siparia, Port-of-Spain Gazette (hereafter POSG), May 6, 1876; Larceny in Siparia, POSG, May 16, 1895).

3 The provenance of the Madonna that now stands in Siparia remains unclear, although the dominant view is that she was erected by Capuchin missionaries from Cumaná in Venezuela 
The faithful include not only Catholics but also non-Catholics, especially South Asian diasporic Hindus, mostly descendants of indentured agricultural laborers who arrived on the island from the mid-nineteenth century. Today, each year on Maundy Thursday and Good Friday, a stream of pilgrims, predominantly Hindu, offer prayers of supplication and thanksgiving to the Madonna in Siparia for curing "sickness"; on Good Shepherd Sunday, ${ }^{4}$ Catholic pilgrims pay homage to the same Madonna, requesting and acknowledging the healing of their "sickness." The faithful know the Madonna by different names: Catholics refer to her as "La Divin," while Hindus call her "Sipari Mai" (or "Siparee Mai"; literally, "Mother of Siparia"). They share the conviction that the Madonna at Siparia cures all "sicknesses," including ill health, emotional and mental disorders, financial difficulties, poor educational achievement, relationship issues, and infertility—whatever the supplicant's religious identity.

Based on archival research and supplemented by ethnographic observations, this article critically revisits the history of La Divina Pastora in colonial Trinidad, focusing on how the spirituality and materiality of the two statues of this Marian image intersected, competed, and reinforced each other: a faircomplexioned La Divina Pastora in northern Trinidad, created and patronized by the Catholic central authorities; and a dark-skinned, miracle-working La Divin/Sipari Mai in Siparia, formerly a peripheral Spanish mission in southern

when they launched a campaign to convert the indigenous population in the mid-eighteenth century (Boodoo 1993, 2000; Borde 1982; Collens 1888; Goldwasser 1996; Noel 1984, 1995). Buenaventura de Carrocera (1968, I:372) argues that the Madonna was brought in by Capuchin friar Francisco de Ateca in 1874. Michele Goldwasser (1996:13) points out that Carrocera's reconstruction is based on the following false premise: "Fr. Francisco de Ateca must be the one who founded (Siparia) (el Padre Francisco de Ateca, que debi-ser quien efectivamente la fund)." On the other hand, Goldwasser (1996:214) draws attention to an epistle written by Capuchin missionary R.C. Poirier (1841) before he departed Cumaná for Siparia: "I am going to dedicate my new church to the Immaculate Conception of Mary, because of the devotion that these people testify for their good mother. I will need a painting or statue of the Holy Virgin." Goldwasser sees this as an indication that the La Divina Pastora was yet to be consecrated in Siparia at this point. In opposition to theories that assume a Spanish origin for the Madonna, local historian Angelo Bissessarsingh (2012) contends that the Madonna in Siparia was originally a local Amerindian spiritual artifact that was transformed by Catholics into the Marian statue for their invocation.

4 Good Shepherd Sunday used to be on the third Sunday of Easter. In the current liturgical calendar adopted after the Second Ecumenical Council of the Vatican (also known as Vatican II, 1962-65), it is on the fourth Sunday in the Easter Season. At Siparia, Feast of La Divina Pastora had been celebrated on the third Sunday of Easter since the nineteenth century and began to be observed on the fourth Sunday of Easter in 1991. See New Date for La Divina Pastora, Trinidad Express, May 1, 199o. 


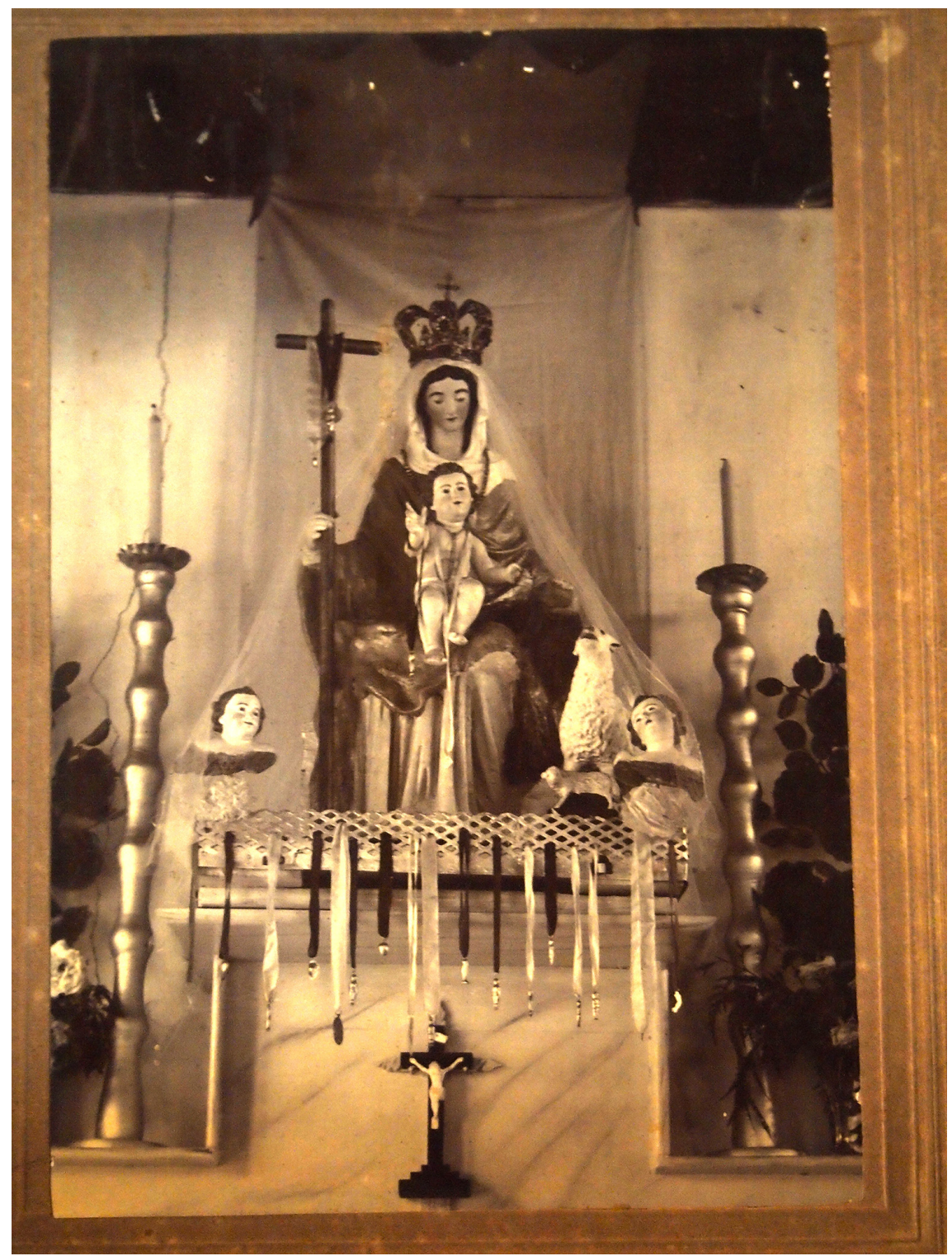

Figure 1 The La Divina Pastora in Arouca (Courtesy of the Archbishop House Archives)

Trinidad. Tracing the trajectory of their lives and relations reveals the complexities of the ecclesiastical history of Trinidad, unearthing contradictions and tensions between the patriarchal making and remaking of religion as a bounded, codified belief and ritual system and a popular praxis of faith for dayto-day substantive issues needing medico-spiritual solutions. 


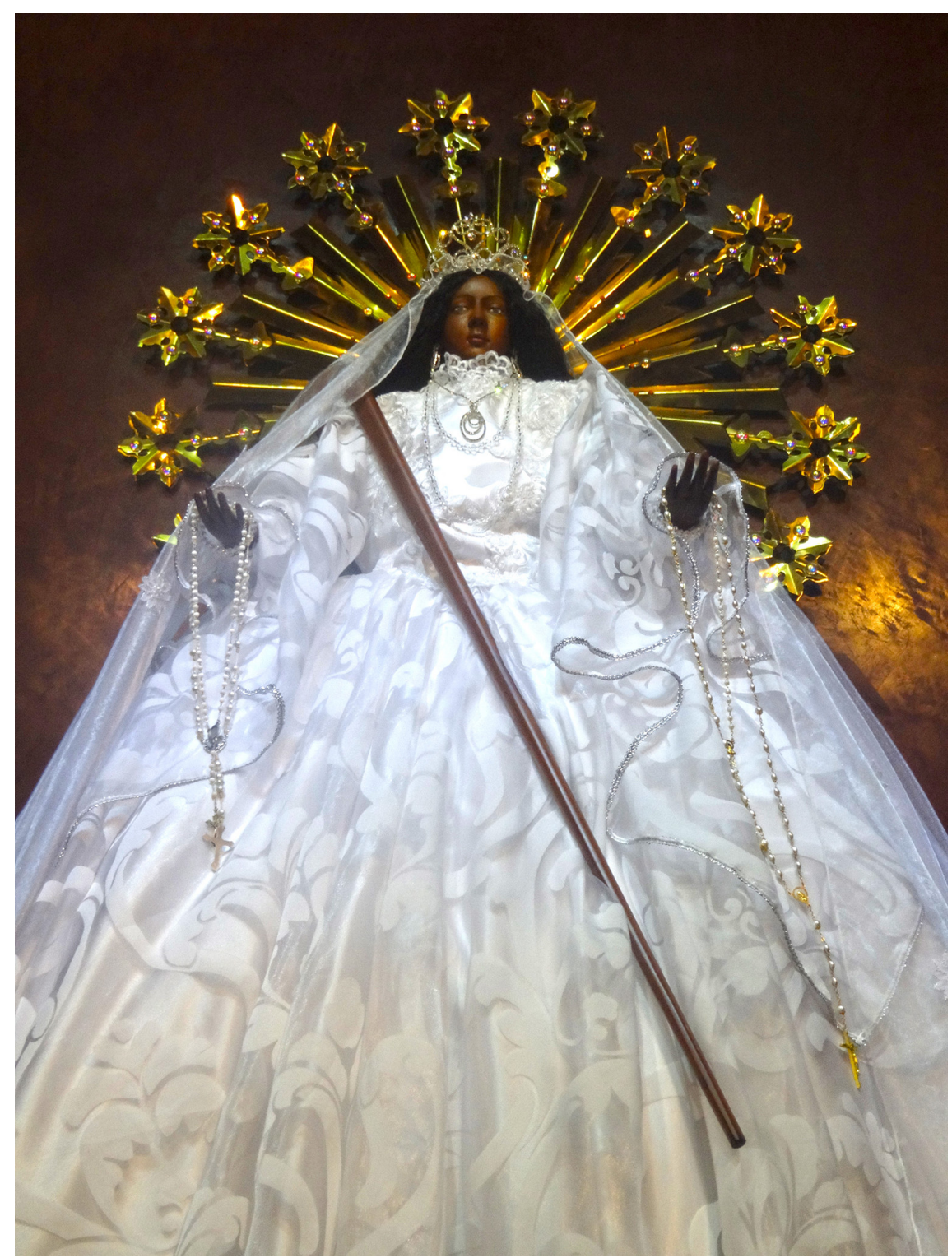

FIGURE 2 La Divin/Sipari Mai in Siparia

The Madonna at Siparia emerged and survived as a venerable object for subaltern South Asian Hindus during British colonial rule, despite belonging to the hegemonic Catholic Church. This has inspired much ethnographic and historical research into this miracle-working Madonna, but simultaneously restricted the scope of exploration into the relations and politics of culture between 
the Catholic Church and the Hindu faithful. However, the implications and significance of Hindu veneration and devotion were broader and more wideranging. First, Hindus developed a reverence for the Madonna at Siparia within the context of acute status inconsistency and recurring conflicts between the Anglican English and the Catholic French Creoles for the colony's religio-moral authority. The rise of La Divin/Sipari Mai had a major impact on Christian ethno-denominational conflicts, driving Anglican criticism of Catholic Marian devotion as Mariolatry on the one hand, while inspiring the Catholic Church to use the apparent power of the Madonna at Siparia to attract Hindus on the other.

Second, extant studies that specifically address Catholic-Hindu relations over the Madonna at Siparia are generally based on the misconception that the Catholic Church, a power-saturated polity of stratified, diverse tenets, ethnicities, and localities, was a "one-column [entry]" (Malinowski 1945:18; Stoler 1989:134) presenting a unified front against the Hindu faithful. However, veneration from Hindus transformed the Madonna at Siparia into an irreplaceable asset and virtue for the competing spiritual and material desires of different segments of the Catholic Church, leading to recurring intra-Catholic conflicts over the custody of the statue and application of its spiritual and lucrative power.

This article focuses on the relationship between the two distinct statues representing La Divina Pastora, and how a holistic approach can allow us to appreciate why and how the dark-complexioned Madonna at Siparia emerged, survived, and thrived as a shared empowering object, despite a colonial obsession with racial-cultural purity and regimes aiming to enforce the boundaries of belonging. Seeing impassioned Hindus flocking to the Madonna in Siparia, the Catholic authorities erected another La Divina Pastora in the archdiocese, who, as a fair-complexioned lady, personified the orthodox mythos of the Marian image and was intended to draw the pagans to the Church. However, conflicts among the Christian communities thwarted the attempts of the Catholic central authority, while creating the conditions for Hindu supplications for miraculous cures to persist and thrive, despite discrimination and repression by the Catholic authorities. The continuing interactions of Catholics and Hindu devotees in Siparia led to the combining of their once divergent practices and worldviews and the transformation of the dark-colored Madonna from La Divina Pastora to La Divin/Sipari Mai, an alternative agentic object that represented various maternal/female bodies, each conforming to distinct religious traditions. 


\section{Mariolatry and "Anglican Ape": Landscape of Marian Devotion}

Harry Hoetink wrote of the Spanish colonies in the Americas: "Spanish political thought, with the support of the [Roman Catholic] Church's prevalent philosophy, acted to preserve a fixed social hierarchy and to maintain the status quo of the different sections of society" (Hoetink 1967:11). Brackette Williams argued that British West Indian colonies were founded on a similar "moral-political bloc," consolidating political-economic and ideological domination (Williams 1991:201).

In this respect, Trinidad under British rule is distinctive, marked by recurring ethno-denominational conflicts within the Christian populations over the colony's religio-moral authority. After the acquisition of the colony by the British Empire (1802), the Catholic Church, with more than half the population among its adherents, retained its hegemonic influence (Joseph 1970; Wood 1968), and Catholicism prevailed as the ethical underpinning of institutions and the "plausibility structure" that enabled meaningful interactions in the formal and informal realms of everyday life (Berger 1967; Wolf \& Silverman 2001). Moving toward a "moral-political bloc," the colonial government enacted the Ecclesiastical Ordinance in 1844, which established the Anglican Church and granted it the largest share of public funding for ecclesiastical matters (De Verteuil 1884:172-73). However, the government was forced to repeal the Ordinance in 1870, which meant the disestablishment of the Anglican Church. This was largely due to the decline in sugar production, the power base of the Anglican English elite, and an upward trend for the cocoa industry, restoring the political influence of French-Creole Catholics (Wood 1968:281301).

In the conflicts, Anglicans, with their traditional view of Mariolatry, claimed Catholic Marian devotion represented the moral corruption of Catholicism: Catholics held the Virgin Mary in nonsacrificial idolatrous reverence (Dulia), which ignored scripture and deflected devotion away from the Holy Trinity (Latria; Schaff 1867:473-75). In 1855, Fr. Vincent Spaccapietra, who was unable to speak English, assumed the episcopate, which enraged the Anglican community (Wood 1968:199-201). An Anglican deacon published a commentary, "Mariolatry in Trinidad":

Never was the spirit of antichrist more wickedly busy in subverting the worship of the one only [sic] Mediator ... [T] his false worship is becoming the corner-stone of the papal apostasy ... The Romish bishop has made great efforts to pervert our people; and the doings of the priests have been such as to excite the attention of one of our legislators. Their veneration 
of the virgin is becoming more and more blasphemous, the Saviour being degraded, and the virgin exalted in his place ... To counteract this in some measure, I composed a prayer for the use of our people: "Let us return unto the Lord; for he hath torn, and he will heal us."5

In the circumstances, in the 186os, the Catholic Church came under the control of the Dominican Order, known for its Marian piety and devotion. The Dominicans believed the Virgin Mary held only a special (though important) status, exemplified by the holy rosary originally given by God to Saint Dominic, the founder of their Order, through Marian intercession (Drane 1857:47). In 1864, Fr. Louis Joachim Gonin, a French Dominican, arrived as the new archbishop, and during the following century, the episcopacy for Port-of-Spain was held by three Irish Dominicans: Patrick Vincent Flood (ca. 1889-1907), John Pius Dowling (ca. 1909-40), and Count Finbar Ryan (ca. 1940-68). During their tenures, there were more than 200 Dominicans in Trinidad, and they held most of the archdiocesan offices and pastorates for the principal parishes (Cothonay 1894, II:118; Coyne 1950:19).

It was when Marian devotion became a contentious issue in the CatholicAnglican rivalry for religio-moral authority that the Madonna at Siparia started to draw the Hindu faithful. The apparently transgressive Hindu adherence provided fertile ground for an Anglican attack on Mariolatry: Catholic Marian veneration was "blasphemous" and inspired the Hindus' ecstatic, idolatrous worship, which reduced the Marian shrine to a disorderly, syncretic space. Driven by this criticism, Catholic authorities developed an irresistible desire to use the appeal of La Divina Pastora for Catholic evangelism, because what had occurred in Siparia, for the Dominicans, embodied Mary's intercessory power and thereby represented the orthodoxy of their Order.

For the Dominicans, the Madonna could be nothing less than the mediatrix in the salvific redemption by her son Jesus Christ. Therefore, against the assaults on Mariolatry, the Dominicans defended the Marian feast at Siparia, but never endorsed the honoring or supplicating to the Madonna of faithful Hindus.

By the turn of the century, the Hindu pilgrimage to Siparia was seeing significant growth and had gained colony-wide recognition, leading to more intense controversy over the celebration of La Divin/Sipari Mai in Siparia. The Churchman, the organ of the anti-Catholic Anglican Church Association, printed a letter from an Anglican deacon in Trinidad:

5 Mariolatry in Trinidad, The Church of England Magazine 38(2) 1855:22-23. 
Mariolatry, [despite] all the safeguards and distinctions that casuistical theology may draw between Latria and Doulia, is not very far from superstition. This was strangely, if it were not for the pathos of the thing we would almost say amusingly, illustrated in a letter from Trinidad in the British West Indies ... Here in the town of Siparia is a famous Spanish shrine of The Divine Shepherdess, La Divina Pastora. Pilgrims may be found here every day in the year, but the great festival is from Easter Monday to the Saturday of that week. A pagan festival essentially, with little prayer or religious service of any kind, but with infinite feasting and revelry in which Brahmin, Mohammedan, Confucianist and Romanist join in a catholic equality, all doing homage to the goddess who has indeed become all things to all men. Indeed, this is perhaps the only shrine in the world where Hindoo, Moslem, Chinese, Creole, Negro and Caucasian join in a worship whose creed has but one article-the beneficent power of the Divina Pastora, whom some call Mary and others Kali. This power is invoked in case of sickness, for the pangs of despised love, for success on the racecourse, and at the gambling bank ... Curiously enough, there is no priest here. It is a purely spontaneous affair. ${ }^{6}$

The letter inspired an immediate, pointed rebuttal from a Dominican friar in Trinidad:

The writer of the article [in The Churchman] evidently depended upon hearsay for the information that he has so generously emblazoned. Initiating his remarks with a ghastly pun upon devotion to the Blessed Virgin Mary, this "casuistical" discriminator between Latria and Doulia proceeds to "knock the eye" out of the Shrine itself. Siparia is the scene of an annual pilgrimage of Catholic Christians ... The ceremonies consist in the celebration of Mass by the pastor and the reception of the Sacraments of Penance and Holy Eucharist by probably four or five hundred pious Christians - not pagans. A procession, in which the image of our Lady is carried, is a devotional practice on the Feast. Before returning peacefully to their respective homes these good people partake of a frugal repast on the roadside ... Possibly they were overlooked in the motley crowd of "Brahmins, Mohammedans, Confucians and Romanists" who joined in "catholic equality, doing homage to the goddess." The troop of Hindoos, Moslems, Chinese, Creoles, Negroes, and Caucasians which this

6 Untitled, The Churchman 78(16) 1901:14. 
imposing juggler has conjured up as an admirable illustration of unity of faith in Mary's intercession, seem to be equally afflicted with the "pangs of despised love." ... [T] he presence of some Brahmins, Confucianists and non-Catholics as interested and edified spectators of the devotions practiced in honour of Mary ... [W] hen the light of divine faith is granted to the Brahmin and Confucianist, he certainly joins the Romanist on grounds of Catholic-Roman "Catholic equality" — and ceases to be a Brahmin or Confucianist. He is not content with imitations in religious worship; he is devoid of tricks peculiar to the Anglican ape. ${ }^{7}$

As evident in their counterargument, for the Dominicans, the Hindus making a pilgrimage to the Madonna were actual or potential Catholic converts, if not "spectators," and represented a "unity of faith in Mary's intercession." La Divina Pastora should have been a powerful intercessor shepherding the pagans to respectable and morally superior Christianity.

\section{Circulation of the Madonna: La Divina Pastora for the "Coolie} Mission"

From the late 186os, amid the Catholic-Anglican conflict, there was another significant transition in the colony's religious landscape: an increasing number of time-expired indentured Hindu laborers began settling in the colony instead of repatriating. ${ }^{8}$ Seeing Hindu religious expression as a menace to moral order, Christian Churches competed to convert Hindus, especially those who resettled in and around Port-of-Spain. ${ }^{9}$ To ensure the influence of the Catholic Church, the Dominicans, both preachers and the laity, instigated various charitable and missionary works collectively called the "Coolie Mission."10

7 Thou Shalt Not Bear False Witness Against Thy Neighbor, Dominicana: A Journal of Catholic Literature 3(2) 1902:21-22; emphasis in original.

8 According to the 1871 census, there were 27,425 South Asians, including first-generation immigrants $(22,880)$ and natives of Trinidad "with Indian parents" $(4,545)$, accounting for a quarter of the colony's population (Clark 1892:19-20). Out of the 129,224 indentured South Asians who settled in Trinidad between 1851 and 1908, only 15,394 (11.9\%) were repatriated (Sanderson Commission 1909:63-4; see also Look-Lai 1993).

9 An important exception was Rev. John Morton's Canadian Presbyterian mission, which focused on Hindus in plantation districts, although it was first granted property in Iere Village in southern Trinidad to convert former African slaves (Morton 1916).

10 Exactly when the Coolie Mission began is uncertain. However, it was a significant moment when in 1871 French Dominican Fr. Mariano Forestier opened Belmont Orphanage (now 
Among the most important was a mission founded by French Dominican Fr. Marie-François Ribon in 1873.

Since the late 183os, the Catholic missions had focused on the eastern edge of Port-of-Spain, the colony's most deprived area, which was populated by emancipated Africans, most of whom were Catholics. ${ }^{11}$ Beginning in the late 186os, this region, formerly dominated by the Catholic Church, transformed itself into the most competitive market for Christian missions with the resettlement of former indentured laborers (Anthony 2001:33; Clark 1892:22-3). Fr. Ribon located his mission at East Dry River on the eastern border of Port-of-Spain "to strike the paganism ... [of] outcasts of India, especially from Madras".12 In furtherance of this goal, he dedicated his mission to La Divina Pastora, setting up the new, fair-skinned Madonna statue ${ }^{13}$ and called it "Siparia Hill," which became known as the "New Siparia."14

Details of the Siparia Hill mission are recorded as follows in eulogistic accounts by Marie-Bertrand Cothonay, Fr. Ribon's peer and a French Dominican friar in Port-of-Spain..$^{15}$ In 1876, Fr. Ribon headed for a village at Gros-Morne Hill, a half mile east of Siparia Hill, to stop "[the] sacrilegious abomination"the rumored immolation of human children for their deity - with catechists who were converts from Hinduism and twelve "apostles" portrayed by students

St. Dominic's Children's Home) in Port-of-Spain, which primarily accommodated children of South Asian descent (Coyne 1950:20). The term "Coolie Mission" was found in documents in different formats at the Archbishop House Archives (hereafter AHA), dating from the early 1910 s to the late 1940 , and there is evidence that the term was later changed to "Indian mission."

11 Casey 1950:10. As of emancipation (1834), 22,359 African slaves resided in Trinidad, about 20,000 of whom had been baptized as Catholics (Bowen et al. 1948:12-13).

12 Cothonay 1893:75-76. Port-d'Espagne, Les missions Catholique: Bulletin hebdomadaire illustré de l'oeuvre de la propagation de la foi (hereafter $L M C$ ), 9 (July):35o. In Trinidad (and other territories settled by South Asian indentured laborers), "Madras" and "Madrasi (or Madrassi)" were derogatory terms for southern India and people of southern Indian origin. Prior to 1870, 4,992 indentured laborers had departed from Madras Port for Trinidad, which represented about 12 percent of the total number of settlers from the Indian subcontinent (Look-Lai 1993:277).

13 Some studies (e.g., De Verteuil 200o; Goldwasser 1996) have argued that a group of planters erected the La Divina Pastora in the archdiocese to discourage their workers from making the pilgrimage to Siparia during Holy Week, which fell during harvesting season. However, this story is unsourced and cannot be confirmed. Further research is needed concerning the relationship between the La Divina Pastora documented in these references and the La Divina Pastora at Siparia Hill.

$14 \quad L M C 9$ (July):35o.

15 This article cites Cothonay $(1887,1893)$, translated from the original French by the author. 
of the Siparia Hill Convent School. While at the village, he preached the gospel in French, English, and the "language of Madras" to the Hindus, despite threats from a cutlass-wielding Brahmin officiant. The congregation fled in awe when Fr. Ribon snatched up three gemstones representing the Hindu Trimurti of Brahma, Vishnu, and Shiva. A sacrificial ceremony of any kind would never be performed in the village again (Cothonay 1887:167-68).

In 1877, on Good Shepherd Sunday, Fr. Ribon returned to Gros-Morne, leading his congregation in procession to celebrate the "brilliant success, whose honor belongs to La Divina Pastora" (Cothonay 1893:76). Leading the procession were 14 children from the convent, each carrying a crucifix, followed by more children, each waving a small banner. Behind them were "coolies reciting the rosary in the language of Madras" and the "image of La Divina Pastora carried by six coolies on their shoulders." The statue was adorned with ornaments, chiffons, and flowers, and surrounded by more "coolies singing hymns in Madras." On their way back to the Chapel of Siparia Hill there was an array of "[Afro-]creoles" who were keen to join the parade and "Protestants [who] were in awe of such a beautiful sight." A Protestant exclaimed, "Look how beautiful it is! These Catholics have the secrets for beautiful ceremonies!" Amid singers and acolytes, Fr. Marie-Dominique Berthet, Dominican superior and curé of the cathedral in Port-of-Spain, gave the Litany of the Most Holy Virgin Mary in Latin to the assembled. Fr. Ribon tried to speak but was choked with emotion and tears. In closing, he managed to offer prayers: "May the Divine Shepherdess touch the hearts of so many poor pagans and bring them to the knowledge of the true faith!" (Cothonay 1893:397).

\section{4 "All Things in Siparia for Siparians": Power of the Place, Power of the Gift}

For the Siparia Hill mission, Fr. Ribon built a chapel and convent school on land he purchased for US\$140 (Guillet 1926:242). How these were financed remains unknown, but there are records indicating that he sought funding from Siparia. In correspondence before the launch of his mission, Fr. Ribon urged Fr. Cornelius O'Hanlon, the curate for Siparia, to send the archdiocese all the offerings given to the Madonna at Siparia (except for a minimal amount to cover operational costs), along with a detailed record of the collection. ${ }^{16}$ Furthermore, he

16 AHA, bx. Parishes $S$, fo. St. Ann's, f. Siparia Hill, C. O'Hanlon to M.F. Ribon, June 23, 1873; AHA, bx. Fathers L-O, fo. O'Hanlon; Ribon to O'Hanlon, July 23, 1873 . 
encouraged Catholics in Siparia to sell the holy unction-known as the curative "La Divina Oil"17_instead of giving it away, provided that the proceeds were also forwarded to Port-of-Spain. ${ }^{18}$ These arrangements were, however, hampered by resistance from lay Catholics in Siparia: the acolytes ignored Fr. O'Hanlon's repeated requests for the donation list, and the custodians refused to turn over the keys to the chapel and offertory boxes. ${ }^{19}$

Siparia had formed part of the archdiocesan hierarchy since it had come under the care of the resident priest at South Oropouche, the northern neighboring parish, in the 1840 . Within the colony-wide Catholic institution, however, Siparia had declined because it was "quickly abandoned" and then "completely ignored" by the archdiocese (De Verteuil 1884:314). This was partly because its location was restricted by geographic conditions, ${ }^{20}$ but more importantly, because Spanish religious and social capital continued to inform the community against the archdiocese, which was increasingly under the control of French and Irish clerics. ${ }^{21}$

A geographic and ethnic enclave, Siparia was impoverished during the Catholic Church's financial crisis caused by the Ecclesiastical Ordinance (De Verteuil 1858:40). Exactly when Hindus discovered the power of the Madonna at Siparia and ritualized their devotion is uncertain, but it is evident that they started to supplicate to this Madonna when isolation and poverty threatened the existence of Siparia. The circumstances made the spiritual and material life of Siparian Catholics increasingly dependent on the Madonna and the piety, devotion, and gifts of the faithful, regardless of their religious identity. While at Siparia to officiate Good Shepherd Sunday Mass for Feast of La Divina Pastora in 1874, Dominican Superior Fr. Berthet was impressed by how critical the appeal of this Madonna to the non-Catholic faithful was and how much their donations had helped Siparian Catholics address their distressing circumstances:

17 A Sanctuary of Our Lady in the West Indies, Monthly Magazine of the Holy Rosary 43:19o.

18 AHA, bx. Parishes S, fo. St. Ann's, f. Siparia Hill, O'Hanlon to Ribon, June 23, 1873; Ribon to O'Hanlon, July 23, 1873 .

19 AHA, bx. Fathers L-O, fo. O'Hanlon, O'Hanlon to Gonin, June 23, 1873; O'Hanlon to Gonin, October 29, 1873 .

20 Day 1852, II:311-22; see also Ciparia, San Fernando Gazette (hereafter $S F G$ ), May 2, 1874; A Trip to Siparia, $S F G$, May 11, 1889 .

21 De Verteuil 1884:314. Governor Ralph Woodford (ca. 1813-28) kept Siparia open to Spanish royalists fleeing the Venezuelan War of Independence, which increased its population from fewer than 100 to nearly 500 , the majority of whom were Spanish-speaking Catholics. 
The sanctuary of the "Divina Pastora," which gives Siparia its celebrity, is all that can be imagined of extreme poverty. It is built of bad "tapia," covered with miserable roofing of leaves ... The interior is not less wretched: you walk on the bare ground, beaten to dust so as not to injure the pilgrims' feet, though the sanctuary is floored ... The statue is certainly not the work of an artist; but to make amends it is richly adorned ... Every year a gift is made to it of one or two robes, and the curé assured us that it had now more than seventy. Offerings are also made of lamps, chandeliers, bracelets, vases of all kinds, and even dolls, earrings, and watches, an endless number of wax candles and the bottles of oil ... Who gives all [these] presents?... Except the chasuble and chalice, given by inhabitants of Port-of-Spain, all the rest have been given at different times by the Chinese and "Coolies." 22

The gifts to the Madonna enabled Siparia to survive and thrive as a Catholic community: when Fr. O'Hanlon assumed the curacy in 1861, Siparia had only "a miserable hut called a Church," but during his tenure (which ended in 1879), he not only became "the first Curé living in his own Presbytery" but also built a new, "splendid chapel."23 More than the architectural improvements, the offerings allowed for the observance of liturgical norms. Among the most popular gifts were gold and silver accessories and adornments along with ready-to-use liturgical items like "wax candles and bottles of oil." Only by selling these valuable donations could the curates purchase the articles and furnishings essential

22 A Sanctuary of Our Lady in the West Indies, Monthly Magazine of the Holy Rosary 43:1899o. In reporting the feast at Siparia, Church documents and colonial print media focused on describing the Hindu pilgrims. There are fewer historical materials available about the Chinese faithful, making it more difficult to explore the implications of their presence for the evolution of the cross-religious devotion to the Madonna at Siparia. This may reflect the difference in how Christian Churches and the European landowning class viewed these subaltern groups, who arrived in the colony as indentured laborers. Chinese were racialized as evolutionarily closer to Whites (e.g., because of their physical features, such as lighter skin) and more adaptable to Euro-Christian values (i.e. their postsettlement conversion to Christianity; see, e.g., Look-Lai 1993). When interviewed by the author of this article, several aged current and former parishioners of Siparia revealed that starting in the 1910s an increasing number of Chinese immigrants settled in Siparia, and that, baptized or not, they played an active role in performing devotions to La Divin/Sipari Mai. For instance, from the 1920 s to the 1940s, in a street procession after the Good Shepherd Sunday Mass, the Madonna was carried on a wooden palanquin (on which something was written in Chinese) donated by the Chinese community in Siparia.

23 AHA, bx. Fathers $L-O$, fo. O'Hanlon, O'Hanlon to Gonin, May 22, 1879. See also La Divina Pastora Roman Catholic Church 1965 and Noel 1995. 
for the performance of the liturgy: "The poorest mission church is richer in ornaments than the Siparia church ... Several jewels of a certain value hang around the Virgin's neck or on her hands. I am going to ask the Archbishop for authority to sell some of them to buy altar linen and ornaments" (Massé 1988, II:254).

Other typical gift items were new clothing for the Madonna. When he visited, Fr. Berthet was "assure[d] that every year a gift was made to the image of one or two robes and it had now more than seventy."24 The curates habitually remade the Madonna's extra clothing into their vestments, and only then could they be properly dressed for the ceremony:

According to the Spanish Custom the statue is dressed with very costly robes, but having too many of them, with the advice of the Dominican Fathers, I carried several to Port-of-Spain, and made some five vestments of them, as we had only two old vestments. A ciborium has also been procured. ${ }^{25}$

After the death of M. Kunes [Fr. O'Hanlon's predecessor], Abbé Rebanit went up, but could not say Mass, there being no Vestments, now there is plenty, made of the robes of D. Pastora. ${ }^{26}$

No record indicates that anyone attempted to remove the Madonna from Siparia during this period. But, given the increasing interference from Port-ofSpain, Siparian Catholics became concerned that their remedial and wealthgenerating Madonna would be taken away, which led to violence toward the curates: ${ }^{27}$ some Catholics in Siparia "insulted a number of times and on one occasion kicked" Fr. O'Hanlon and later "seized the bridle of his horse [and] beat" Fr. Armand Massé, Fr. O'Hanlon's successor. The acting curate who succeeded Fr. Massé "had to disperse [Siparian Catholics] and make them leave [his horse's] bridle with his revolver." And then a Siparian Catholic "broke the head of the groom [serving Fr. Clunes, Fr. Massé's replacement]." On Good Friday in 1892, "about 100 people from (South) Oropouche had to go to Siparia with sticks and cutlasses to deliver [Fr.] Rychaert [Fr. Clunes's successor] from

24 A Sanctuary of Our Lady in the West Indies, Monthly Magazine of the Holy Rosary 43:19o91.

25 AHA, bx. Fathers $L-O$, fo. O'Hanlon, O'Hanlon to Gonin, October 19, 1872.

26 AHA, bx. Fathers L-O, fo. O'Hanlon, O'Hanlon to Gonin, May 22, 1879.

27 Fr. Aloysius Osenda to Abp. Vincent Flood (ca. February 1893), transcribed by Fr. Modesto Osenda in the Baptismal Record for Siparia for 1906-13. 
the hands of Siparian rowdies." On New Year's Eve of that year, ten Siparian Catholics "entered the Church ... with the object of carrying away the Divina Pastora statue. They were however prevented by the Constables." Shortly before this incident, one of the "intruders" had threatened the new curate, Fr. Aloysius Osenda, by roaring: "All things in Siparia for Siparians! No priest, no bishop, no governor here."28

"To Canalize [Rather] than to Stop": Gendered Care and the Sexualized Body of the Madonna

Archbishop Dowling hoped to rebuild the Coolie Mission, which had been moribund since Fr. Ribon's death in 1880 (Cothonay 1894:228), and he attempted to establish effective control of the Madonna at Siparia. Siparia was consecrated as a parish with a resident priest in 1906. Shortly after assuming office in 1909, Archbishop Dowling wrote to Fr. Modesto Osenda, the first parish priest for Siparia, requesting that he no longer accommodate annual Hindu pilgrims on the grounds that their time-absorbing devotion compromised Catholic liturgical observance. ${ }^{29}$

Fr. Osenda arrived in Trinidad in 1893, replacing his ailing brother Aloysius, and he held the pastorate for Siparia until his death in $1924 .{ }^{30}$ Unlike earlier fathers who cared for Siparia, this Siparia's longest-serving priest developed a rapport with the parishioners and the faithful of the Madonna. Of crucial significance was his relationship with Mary Bartlett, a lay minister called "Ma Mayute," beloved — and feared — for her attachment to La Divin/Sipari Mai. Her life was built around her faith in this Madonna, and as a result she left her home in South Oropouche to devote herself to caring for the statue. She donated most of her inherited family properties in and around Siparia to the parish, which paid for the reconstruction of the chapel and presbytery. Her exceptional faithfulness and dedication to La Divin/Sipari Mai gave this lay Catholic immense

$28 S F G$, February 3, 1893. On January 28, 1893, the South Oropouche Magistrate's Court found them guilty. The leader "was sentenced to one month's imprisonment, with hard labour, for threatening to shout Corporal Codrington." Concluding the trial, the magistrate proposed: "The residents of Siparia are a most rowdy set. The Police Force should be increased in number."

29 AнA, bx. Parishes S, fo. Siparia, f. Mission to Indians, 1912-, Dowling to Osenda, February 24, 1909; Osenda to Dowling, March 22, 1909; Osenda to Dowling \& E.C. Hughes (Immigration Office), March 29, 1909.

$30 \quad$ The Catholic News (hereafter $C N$ ), March 15, 1924. 
influence over the parish. ${ }^{31}$ Vicar General Vincent Sutherland expressed concern about his appointment as the priest for South Oropouche: "I am really afraid of my life in the neighbourhood of Bartlett, Fr O's [Osenda's] protégé in whose name all his money is invested."32

What is most significant is that Fr. Osenda gave Ma Mayute full authority to make arrangements for the Madonna for the feast, going beyond daily care. She organized a group of female parishioners selected for their ability to create the Madonna's custom-fit clothing. Each year, on the day before Good Shepherd Sunday, they changed the Madonna into a new robe and gown in secret-no man was admitted, including the parish priest. ${ }^{33}$ The service of the Madonna became strictly gendered, which progressively sexualized the body of La Divin/Sipari Mai, thus restricting the parish priest's authority concerning custody of the Madonna. It was difficult for Fr. Osenda to act on the archdiocese's request to outlaw the Hindu pilgrimage, even though he too felt that it was blasphemous.

In the circumstances, growing pressure for an outright ban on the Hindu pilgrimage presented a dilemma for Fr. Osenda: on the one hand, he was urged to explore ways to enable the Hindus' continued devotion; on the other hand, he needed to prove that their worship had "nothing to do with the ceremonies of Catholics":

Certainly I was sorry to find that customs [sic] here and if it was in my power I had suppressed longtime; but in the circumstances, I tried to suppress the abuses, try little by little to discourage the Coolies, not because I think that there is any desecration of Church, but because this fete is always a great worry for me; and I would be thankful if it could be suppressed, but in my opinion, I believe that [it] is better to canalize the water than to stop it all at once. ${ }^{34}$

To "canalize" the tide of Hindu pilgrims, Fr. Osenda implemented distinct festive arrangements: first, the Madonna was made available for the Hindu pilgrimage only on Good Friday, and Catholics were instructed to discontinue

\footnotetext{
31 Siparia's God-Mother Passes Away: Child of La Divina Pastora, $c N$, July 19, 1966. See also Noel 1984.

32 AHA, bx. Parishes S, fo. Siparia, f. Mission to Indians, 1912-, V. Sutherland to Dowling, May 6, 1912 .

33 The Mirror (hereafter MIR), April 9, 1902 and May 6, 1912.

34 AнA, bx. Parishes $S$, fo. Siparia, f. Mission to Indians, 1912-, Osenda to Dowling, June 29, 1915 .
} 
their tradition of paying respect to the Madonna and to "stay away from the Church until cleared of Coolies for Mass [of the Presanctified] from four o'clock [in the afternoon of Good Friday]."35 And only on Good Shepherd Sunday was the Madonna taken down from atop the high altar (installed when the new chapel was completed in 1907) and placed within reach of Catholic pilgrims. ${ }^{36}$

In opposition, Archbishop Dowling continued to urge Siparia to abandon the Hindu pilgrimage, which was now a spatiotemporally separate feast, calling it by the derogatory title of the "Coolie Fête."37 Eventually in 1916 (and again in 1917), at his request, ${ }^{38}$ the colonial government issued a proclamation:

\section{NOTICE TO ALL INDIANS}

HIS GRACE THE ARCHBISHOP desires it to be made known to all Indians that "The Coolie Fête at Siparia" ... has been totally abolished and will consequently not be held this year ... at the Roman Catholic Church of Siparia, as the custom has hitherto been: and it is hereby notified to all persons concerned that such measures will be taken by the Government to protect the Church from being entered as may be considered advisable. ${ }^{39}$

35 AнA, bx. Parishes S, fo. Siparia, f. Mission to Indians, 1912-, Osenda to Dowling, June 29, 1915 .

$36 \quad C N$, February 23, 1907; MIR, April 17, 1907; $C N$, April 19, 1958.

37 "Fête" is now loaded with positive meanings, but in nineteenth-century Trinidad, in particular when applied by the English segment of the population, this French-derived term often carried the derogatory connotation of merrymaking of a licentious and debauched kind disguised as a religious observance, as opposed to a ceremonial "festival" (Allsop 1996:228; Winer 2009:342-43). The term "coolie fête" had circulated in the colony since the 1870 . With the expansion of the Coolie Mission, this moniker was used for South Asian religious expressions deemed a menace to the colonial moral order. For applications of the moniker in the nineteenth century, see, e.g., Khan 2004; Korom 2012; McNeal 2013 .

38 For instance, AHA, bx. Parishes S, fo. Siparia, f. Coolie Fête, 1909-1917, Gov. J.R. Chancellor to Dowling, March 17, 1917 .

39 The proclamation was authorized by Arnauld de Boissiere, protector of immigrants at the Immigration Office, on April 12, 1916 and March 2, 1917. POSG published it on April 13, 15, and 18, 1916, and March 9-11, 13-18, 20-25, and 27-30, 1917, and $c N$ printed its translation in French-derived Creole (March 4) and Spanish (March 11) in 1916, and in Hindi (March 31) and Spanish (April 7) in 1917. 
While urging Siparia to discontinue the "Coolie Fête," Archbishop Dowling stationed leading priests of the Coolie Mission in neighboring parishes of Siparia, so that everyone would know the archdiocese's views concerning the custody of the Madonna at Siparia.

In 1912, at his request, Louis E. de Verteuil, an estate owner from an influential Catholic French-Creole family, visited Siparia for an "inspection." Arriving "after [the] midnight of Holy Thursday when ... the disorder reached [its] climax," De Verteuil became preoccupied with "things which [he] hope[d] never to see again." His report to Archbishop Dowling numerated the demeanors and modes of devotion that he claimed were peculiar to the Hindu pilgrims:

1. The street near the Church was packed with coolies \& others; as also the Church grounds and the Church itself;

2. Coolie dancing (which I understand to be an act of Thanksgiving) to the accompaniment of the beating of drums was taking place at the end of the steps before the main entrance to the Church;

3. Benches or pews had been removed;

4. Oil was, to all appearance, being sold within an enclosure near the end of the Church;

5. Coolies were stretched out on the floor-at the sides of the Churchapparently sleeping or resting - while others were going to and fro;

6. Smoking was indulged in the Church by one or more of them;

7. There were many, at the altar, apparently praying; infants were made to bow down \& kiss the altar \& money offerings were freely thrown or put into a receptacle which was on the altar;

8. The noise \& disorder in the Church — generally—was shocking and I do not believe that anyone who did not know the contrary would ever be convinced that he was in a Catholic Church. Men \& women-many of the former with hats on - moved up \& down talking — evidently with the object of calling companions at a distance-shouting at them as if they were in the streets;

9. The Blessed Sacrament was kept in the Sacristy, but I met only the faithful there;

10. From a little room attached to the Presbytery which is on the opposite side of the street, oil was apparently being sold. ${ }^{40}$

4 AнA, bx. Parishes S, fo. Siparia, f. Mission to Indians, 1912-, L.E. de Verteuil to Dowling, May 31, 1912. 
Following the report, Archbishop Dowling appointed the Irish Dominican Vincent Sutherland as parish priest for South Oropouche. ${ }^{41}$ Fr. Sutherland, the long-serving vicar general, had spearheaded the reconstruction of the Coolie Mission in the archdiocese. As part of his responsibility, in 1910 he performed a "field survey" in Boissiere Village. This farming community north of Port-ofSpain was of concern to Dowling because, like East Dry River in the 1870s, it was populated by formerly indentured South Asians, principally Madrasis (Procope 1980). Fr. Sutherland found that "the greater number by far of the [village's] residents was Indians [who] were pagans" and made Dowling a proposition: "If the chapel at Siparia were transferred to Boissiere Village, a lot of useful work could be done for Indians." ${ }^{2}$ In 1915, after Fr. Osenda's proposal that it would be better to "canalize than to stop," Fr. Sutherland, now the priest for South Oropouche, advised the archbishop to seize control of the Madonna at Siparia, "detain[ing] Fr Osenda in Oropouche."43 The proclamations in 1916 and 1917 regarding the cancellation of the "Coolie Fête" were issued "because the Parish of [South] Oropouche [viz. Fr Sutherland] asked to abolish the fete." 44

Furthermore, in early 1917, Archbishop Dowling used his influence to make Fr. Hyacinthe Koos, the vicar general in Grenada, Fr. Sutherland's successor. Dowling was desperate to have this English Dominican in the position because of his missionary experience in India and competency in "coolie languages," despite opposition from the Colonial Office, due to his German lineage. ${ }^{45}$ Upon arrival in Trinidad in 1919, Fr. Koos took over the Coolie Mission; in 1921, he assumed the pastorate for South Oropouche with expanded authority over Debe and Penal, the pastoral districts of Siparia with the highest concentrations of Hindus (Trinidad 1923:19-20).

In 1914, Archbishop Dowling placed the parish of Erin, south of Siparia, under the authority of the friars from the abbey at Mount Saint Benedict (LeeSing 1950:3). The abbey was founded in 1912 by Portuguese-speaking Benedictine monks fleeing persecution in Brazil under the patronage of Abp. Dowling. In return, Dowling requested that the Benedictines support the Dominicans'

\footnotetext{
41 AHA, bx. Parishes S, fo. Siparia, f. Mission to Indians, 1912-, Sutherland to Dowling, May 6, 1912.

AHA, bx. Parishes S, fo. Siparia, f. Mission to Indians, 1912-, Sutherland to Dowling, October 2, 1910 . AHA, bx. Parishes S, fo. Siparia, f. Mission to Indians, 1912-, Sutherland to Dowling, May 7 , 1915 .

$44 \quad C N$, February 26, 1916 and March 24, 1917.

45 Aна, bx. Parishes S, fo. Siparia, f. Mission to Indians, 1912-, H. Koos to Dowling, April 17, 1917; Koos to Dowling, September 26, 1917.
} 
Coolie Mission (Tierney \& Vandenbussche 2012:233-42). He assigned Benedictine abbot Anselm Romano as "interim priest" for Siparia when ill health prevented Fr. Osenda from performing his pastorate. ${ }^{46}$ No resident priest was appointed after Fr. Osenda's passing in 1924. Siparia remained under the charge of Abb. Romano and two other Benedictines stationed at Erin until a new parish priest was appointed in 1929 .

In 1928, one of these Benedictines adopted repressive measures against the Hindu pilgrimage. This was somehow related to the fact that in that year Archbishop Dowling would be the first archbishop to say Good Shepherd Sunday Mass at Siparia. ${ }^{47}$ Nevertheless, the Hindu pilgrims completed their annual devotion. ${ }^{48}$ It has been argued that although the "parish priest" forced the Hindus out of the chapel and shut the doors, he eventually permitted their devotion because the pilgrims threatened to burn down the church (Boodoo 1993:387, 2000:69; Goldwasser 1996:229). The Hindu pilgrims may have resisted, but the Benedictines' attempt was also hampered by opposition from lay Catholics in Siparia. After the incident, acolytes, caretakers of the Madonna, and other influential parishioners addressed a joint letter to Archbishop Dowling indicating their dissatisfaction with the interim pastorate of the Benedictines and requesting the earliest possible appointment of a new resident parish priest. ${ }^{49}$

There are few historical materials from which we could learn what happened to the light-skinned statue of La Divina Pastora at Siparia Hill with the fall of the mission, except that she was re-enshrined at the Church of the Holy Trinity, the parish church of Arouca, by the turn of the nineteenth century. ${ }^{50}$

In October 1917, the Virgin Mary appeared before children in prayer at the feet of the La Divina Pastora in Arouca. According to the testimony of the witnesses, "[o]n the First Friday of the month [October 5, 1917]," about 200 people saw "an extraordinary [yet] undeniable fact":

$46 \quad$ Trinidad Guardian (hereafter $T G$ ), February 28, 1924.

47 AHA, bx. Parishes D-E, fo. Erin, A. Romano to Dowling, May 23, 1928; TG, February 28, 1928.

$48 \quad$ POSG, April 25, 1928.

49 AHA, bx. Parishes $S$, fo. Siparia, Siparia Presbytery to Dowling, July 14, 1928.

$50 \quad C N$, April 18,1902 . Exactly when and why the La Divina Pastora from Siparia Hill was transferred to Arouca remains unknown. The fact that Arouca was under the pastorate of Fr. O'Hanlon, the former curate for Siparia, from 189 o to 1892 may have had something to do with the re-enshrinement of the La Divina Pastora. 
The statue was placed in the middle of the church of Arouca for the Triduum of prayers preceding the pilgrimage. About half past two o'clock on the eve of the pilgrimage which was about to be made in honour of the Mother of God to obtain "Peace" through her powerful intercession, a group of little ones from the Convent school went in the church to pray before the statue and were astonished to see tears flowing from the eyes of Our Blessed Lady. Trembling with emotion, some ran to call nuns while the others continued to pray aloud. One of the sisters went with the children to the church and was amazed to find the statue weeping. She went immediately to call the other sister. Soon the schoolmaster, teachers, pupils and about two hundred persons of every denomination were there to witness the undeniable fact. The tears continued to flow quite naturally until about five o'clock. The Sisters, joined by the faithful, continued to recite the Rosary and offer prayers aloud all the time. Unfortunately, the Parish Priest was absent on the occasion. ${ }^{51}$

Shortly before the event, Archbishop Dowling had been invited to say mass at this Church of the Holy Trinity, during which he claimed that the Madonna in the parish was "the ancient statue of 'La Divina Pastora,' formerly honoured in the Church of Siparia Hill"; the congregation "knew nothing about it."52

Arouca, like Erin, came under the authority of the Benedictines in 1914, and at the time of the Marian apparition, the parish priest was Dom. Ambrose Vinckier, one of the three founding friars of the abbey (Coyne 1950:20). Dom. Vinckier apparently persuaded himself that the appearance of the Virgin Mary would empower the Madonna, who would gain a large following, thereby giving crucial momentum to the Coolie Mission. He sent Archbishop Dowling the testimony concerning the apparition and the photograph of the La Divina Pastora that was among the late Archbishop Dowling's belongings (see Figure 1), along with a letter requesting authorization for the initiation of the "Arouca Society of La Divina Pastora":

Here the statutes included command of a new society that they want to establish in this parish of Arouca in honour of the Blessed Mary under the title "The Divina Pastora." The devotion to the Divina Pastora is growing rapidly and the parishioners are desirous of permission to set up a society in which they can devote themselves entirely and even publicly to the

52 AнA, bx. Parishes A, fo. Arouca, Vinckier to Dowling, n.d. (ca. 1917). 
Blessed Mary. Exceeding [sic] great are the favours received through the intercession of the Divina Pastora; to her is attached without the slightest doubt a great number of conversions of Protestants and Indians. Every day public prayers are made for converting them by innocent children of the school before the altar of the Divina Pastora ... [T] he statue shall be fully applicable for the conversion of the Indians. ${ }^{53}$

In February 1920, the Society was consecrated by Archbishop Dowling and launched under the bylaws, which provided that the "members must daily pray for the conversion of sinners and unbelievers, especially for the conversion of $[\mathrm{P}]$ rotestants and pagans" (Article XII); and the "membership fees" and "offerings to a box placed near the altar of La Divina Pastora" would be "used for the propagation of the faith amongst the Indians of the parish" (Articles IV and VII); and "[T] he statue [would] be carried in solemn procession ... on the second Sunday after Easter, feast of La Divina Pastora" (Article VI). ${ }^{54}$

On May 13, 1917, in Fátima, a village in central western Portugal, "a lady dressed in white, shining brighter than the sun" appeared to three shepherd children, guiding them to "say the Rosary to bring peace to the world and an end to the war." Over the next five months, the lady returned to these children on the thirteenth day of each month, and on October 13 made her final appearance, performing now the famous "miracle of the sun" before a great crowd of pilgrims (Ryan 1939). Today, this lady, now known as Our Lady of Fátima, is one of the most celebrated Marian images, followed by millions of the faithful around the world.

The La Divina Pastora at Arouca, which was claimed to have originated in Siparia Hill, shed tears at this critical juncture in modern Catholic Marian devotion. The first of the six monthly apparitions at Fátima occurred just after the "Coolie Fête" for La Divin/Sipari Mai concluded, despite the reissued proclamation banning the pilgrimage. And the La Divina Pastora at Arouca wept when many were eagerly awaiting the prophesied miracle at Fátima. As in the case of the appearances of Our Lady of Fátima, the Virgin Mary manifested herself to

53 AHA, bx. Parishes A, fo. Arouca, Vinckier to Dowling, n.d. (ca. 1917).

54 AHA, bx. Parishes A, fo. Arouca, Arouca Society of La Divina Pastora, 1920. "Rules and Privileges of the Society," unpublished church brochure. 
unattended, faithful children in appealing for peace in Arouca. However, following the Marian manifestation, Our Lady of Fátima inspired a global wave of Marian devotion, whereas the La Divina Pastora at Arouca did not gain a large following, still less make converts from Hinduism. Meanwhile, beginning in the 1920s, La Divin/Sipari Mai continued to earn faith and devotion, attracting record numbers of pilgrims to Siparia for the "Coolie Fête" and the Catholic Mass feast each year, despite discrimination and a series of repressive measures by the archdiocese. ${ }^{55}$

It was in this context that Irish Dominican Rev. Count Finbar Ryan assumed the archbishopric from Dowling. He was known for his devout faith in Our Lady of Fátima, as illustrated by his authorship of the first book in English concerning this Madonna (Ryan 1939). Shortly after his inauguration in 1940, Archbishop Ryan introduced an annual six-month-long Fátima devotion, from May to October; in 1943, he reconsecrated the archdiocese to the Immaculate Heart of Mary, designating the chapel at Laventille, a parish in the hills east of Port-of-Spain (including where Siparia Hill used to be), as the national Marian shrine to honor Our Lady of Fátima. ${ }^{56}$ Under his aegis, Our Lady of Fátima quickly established herself as venerable object for many, and monthly Fátima devotions became a new Catholic tradition in Trinidad. Atop the chapel in the hills of Laventille, a 3o-foot stone statue of Our Lady of Fátima has overlooked the archdiocese since its installation in 1947 to commemorate the thirtieth anniversary of the Fátima apparitions. ${ }^{57}$

Amid the rise of Our Lady of Fátima as the national patron saint, in 1946 the La Divina Pastora at Arouca was removed from the Church of the Holy Trinity and enshrined in the oratory rebuilt in Lopinot, a mountain farming village in the pastoral district of Arouca (Chauharjasingh 1982) —as if to get this Madonna away from the public and obscure the fact that the Catholic authorities had been obsessed with her. On May 13, 1957, at the Chapel of Laventille, Archbishop Ryan told pilgrims celebrating the fortieth anniversary of the Fátima apparitions: "There are people living today who can recall that in the very week Our Lady was appearing in Fatima persons saw an apparition in Trinidad of Our Lady weeping," but he did not mention that it was the La Divina Pastora who wept. ${ }^{58}$ Our Lady of Fátima became the patron saint of Trinidad as she earned worldwide recognition and devotion after one of the three visionaries published a sequence of her memoirs in the late 1930s and the apparition

$55 \quad P O S G$, May 6, 193O; TG, April 12, 1932; POSG, April 25, 1939.

$56 \quad C N$, August 21, 1943; POSG, August 17, 1943.

$57 \quad C N$, May 17, 1947; POSG, May 20, 1947.

$5^{8}$ Our Lady Weeps for Trinidad, Catholic Herald, June 28, 1957. 
was recognized by the Church as an actual manifestation in the early 1940 (Fox 1982; Maunder 2016). Nevertheless, in Trinidad, behind the rise of Our Lady of Fátima was an agony of desire among the Catholic authorities, caused by unrequited love for the Madonna at Siparia, La Divin/Sipari Mai, who was expected to serve their Coolie Mission by converting a mass of Hindus to Catholicism through her intercessory power.

British-ruled Trinidad was marked by the enduring ethno-denominational conflicts between the Catholic French-Creole and English Anglican elites over the religio-moral authority. In the conflicts, the role and veneration of the Virgin Mary in Christianity became the most contentious doctrinal and liturgical issue, particularly from the late 186os when the Catholic Church came to be dominated by the Dominicans - known for their Marian piety and devotionand the Anglican Church was disestablished. During the same period, the Madonna at Siparia began to draw the subaltern Hindu faithful, thereby becoming a focus of attention in the Catholic-Anglican conflicts: Anglicans condemned the rise of La Divin/Sipari Mai as representing Catholic Mariolatry, and against which the Catholic Church strove to apply her power to attract Hindus.

The political use of the Madonna's transgressive power prompted conflicting desires among the Catholic authorities. The Dominicans were eager to take advantage of the power for the Coolie Mission, but they were also repulsed and terrified by the ways of Hindu worship, which they saw as another case of the "sacrilegious abomination" that the Coolie Mission was desperate to repress. Created for the Siparia Hill mission, which was the pioneering Coolie Mission, the fair-skinned La Divina Pastora was intended to resolve the contradictions, enabling the Dominicans to draw on the appeal of the Madonna for Catholic evangelism as well as restoring her rightful image, which was deserving of orthodox Catholic Marian piety and invocation.

The Catholic authorities' attempt to formalize the role of their version of the La Divina Pastora involved circulating a discourse in which it was stated that devotion to La Divin/Sipari Mai was morally questionable. In this regard, the conjunction of racially contrasting statues had critical implications. As other scholars have argued (for example, Mahabir 2007), the dark complexion of the Madonna at Siparia may have inspired and enabled subaltern Hindus to reconstruct their traditional worship of similarly dark-colored female divine manifestations, represented by Kali Mai, with this Madonna as a murti 
(godly effigy). However, even more important was the process of racialization prompted by the concurrence of white- and dark-colored statues of the same Marian image. Despite their diverse phenotypic attributes, South Asian immigrants were positioned on the lowest fringe of the color-graded stratification of this plantation society on the grounds of their primordial attachment to "spurious" non-Christian faiths. "Indian religions," the most visible cultural and behavioral idiosyncrasy of South Asian settlers, were referenced by Christians as the iconic symbol of their otherness and moral inferiority. Religion operated like race, and they engaged with one another and were therefore intelligible as they related to each other. Within the "articulated discourses" of race and religion (Khan 2004), to delegitimize the Hindu adherence and disavow its implication for Catholic Marian piety, the Catholic authorities, not the faithful, drew attention to the "phenotypical" trait of the Madonna at Siparia and contended that her dark complexion caused Hindus to mistakenly identify this Marian statue with their goddess and that this inspired their transgressive, ecstatic adoration. ${ }^{59}$

The Catholic authorities also focused on the ethnic origin of the Madonna at Siparia and imputed the idolatrous Hindu worship to her representation and performance of "Spanishness." Coinciding with the rise of the Coolie Mission in the archdiocese, the curates for Siparia became concerned about what the Madonna was wearing and how she was dressed, reversing their earlier apathy. Fr. O'Hanlon requested that the caretakers "change the [Madonna's] dress every day ... by advice from Dominican fathers." ${ }^{\prime 0}$ Fr. Massé, O'Hanlon's successor, suggested a reason why the Dominicans paid attention to the Madonna's clothing: as the new curate for Siparia, he found it offensive that the Madonna came off as "the Spanish Virgin" in tainted, miserable dress and rushed to get her changed into "dresses of very good taste," which would make her look more like "the Holy Virgin in Rome" (Massé 1988, II:253-54). For French and Irish Dominicans, the Spanish heritage in Catholicism was a quality of otherness, and for La Divina Pastora to represent their Coolie Mission, this Spanish Madonna had to be de-Hispanicized.

Nevertheless, the existence and power of the "legitimate," light-hued La Divina Pastora were completely contingent on those of the dark-complexioned La Divin/Sipari Mai, whom the Catholic authorities intended to disempower. While questioning the authenticity of the Madonna at Siparia, the Catholic authorities replicated the arrangements through which the Madonna exercised Gonin, October 29, 1873; What I Heard About Siparia's "La Divina Pastora." $C_{N}$, May 5, 1962. 
her power to attract Hindus in Siparia. For instance, Fr. Ribon called his Coolie Mission Siparia Hill or New Siparia and launched an annual procession celebrating La Divina Pastora on Good Shepherd Sunday. Fr. Cothonay, who documented the Siparia Hill mission, depicted the congregation of the mission as "descendants" of the celebrants of La Divin/Sipari Mai, seeing them as faithfully reenacting the feast at Siparia in the feast at New Siparia (Cothonay 1893:77). And with the Marian apparition, the archdiocese, along with the Benedictines at the abbey, initiated the Arouca Society of La Divina Pastora and established the custom of an annual procession honoring La Divina Pastora on Good Shepherd Sunday.

The elite reenactment of transgressive subaltern spiritual power failed. The "legitimate" La Divina Pastora never gained a large, colony-wide following, and she was unable to earn much faith and devotion from Hindus. This was not simply because she was White-skinned but more because she was politically created for evangelism based on the conviction of the ubiquitous presence of the Virgin Mary and her boundless virtue. The archdiocese's La Divina Pastora could not cure "sicknesses" and inspire faith, because it was a mere artifact that bore no relation to the lived experience of the faithful.

On the contrary, an entanglement of intra-Christian and intra-Catholic conflicts created the conditions in which the dark-complexioned Madonna at Siparia was transformed from La Divina Pastora, a conceptual Marian imagery, to La Divin/Sipari Mai, a miraculous, agentic personhood whose power and virtues were embedded in the specific locality and historicity and the relevant human social and material networks. Hindus were involved in this process of transformation and empowerment from the beginning. Thus, it is wrong to believe that the Hindus embarked on their devotion for the already established power of the Madonna by crossing religio-moral boundaries. The Madonna at Siparia had been revered by Catholics since she was set up as the tutelary saint in the Mission. By the late 186os, Hindus had discovered the medicospiritual power they needed in this Madonna and had ritualized their supplication. Their affection for, and devotion to, the Madonna were so fervent and aberrant that Catholics in Siparia were repelled and terrified. ${ }^{61}$ However, in a complication of the conflicts over the miracle-working Madonna among Christians, Siparian Catholics' "desire for possession or subjugation" was restrained and forced to be "satisfied through combinations and events other than fight" (Simmel 1955:27), allowing Hindu and non-Catholic supplication to persist and

61 See, e.g., AHA, bx. Fathers $L-O$, fo. O'Hanlon, O'Hanlon to Gonin, June 23, 1873; O'Hanlon to Gonin, October 29, 1873; De Verteuil 200o:226. 
flourish. For living by faith despite impoverishment, Catholics in Siparia had to accept, albeit reluctantly, Hindu supplicants, whose devotional worship was marked by the virtue of generosity and the practice of giving (Dāna; Heim 2004; Michaels 2004). Material and financial needs created the initial context for boundary-crossing; however, Hindu devotion gradually forced Catholic liturgical principles and practices for the care and celebration of the Madonna to be reworked. The Catholic authorities' overt repression began in the 191os, leading to the proclamation banning "the Coolie Fête at Siparia." However, there had been no such an independent observance. As documented earlier, in consequence of the suppression, the Hindu pilgrimage materialized as a spatiotemporally separated "Fête" that had "nothing to do with Catholic ceremonies." During the preceding half a century, every year on Good Shepherd Sunday, Hindus had performed a pilgrimage within the sanctuary, side-by-side with the Catholic and other religious faithful. ${ }^{62}$ The constant interactions of lay Catholics vis-à-vis Hindu devotees in the temporal and spatial limits at Siparia, an isolated, marginal community, led to comingling of their originally divergent practices and worldviews, as well as the transformation of the dark-colored Madonna into La Divin/Sipari Mai, an alternative spiritual construction that represented various maternal/female bodies, each conforming to distinct religious traditions. Gifts given to La Divin/Sipari Mai by the faithful functioned as threads that wove various religious expressions into the fabric of a community of faith focused on piety and reverence for maternal virtue. It was a "microcommunity with a nascent religion that [was], in a real sense, its own" (Mintz \& Price 1976:23), within which only La Divin/Sipari Mai could exercise her miraculous spiritual power.

An illuminating example of this power is "La Divina Oil." Anointing the sick with blessed oil is a sacrament defined by the Catechism of the Catholic Church and had most likely been performed at the Siparia mission whenever required and financially feasible. Unlike sacramental oil, the virtue and efficacy of "La Divina Oil" were contingent on the charity of the faithful. During the feast, as a part of their worship, Hindu and other non-Catholic pilgrims donated oil

62 Rézeau 1995, II:335. On Good Shepherd Sunday in 1884, as recorded by Fr. Armand Massé, "[a]ll day long the pilgrims ... prostrate[d themselves] at the feet of La Divine-French, English, Spanish (both white and colored), Portuguese, Chinese, Indians, mainly pagans" (Rézeau 1995, II:335). By the turn of the century, Hindus had become the most engaged celebrants among an even more mixed crowd of pilgrims: as cited earlier, in 1901, an Anglican deacon noted that the assembled at Feast of La Divina Pastora in Siparia were a large number of Hindus, along with the Catholics, Muslims, and Buddhists. See Untitled. The Churchman 78(16) 1901:14; Thou Shalt Not Bear False Witness Against Thy Neighbor, Dominicana: A Journal of Catholic Literature 3(2) 1902:21-22. 
for the lamps placed before the Madonna, and then all the pilgrims, including Catholics, collected oil from the lamps and were cured of their sickness by it:

During the three days of the feast ... several persons ... take this oil; it could then be obtained in abundance, as more than fifty lamps were burning night and day before the miraculous image. Last year, by simply rubbing the part affected with the oil of the "Divina Pastora," the parish priest himself was cured of a pain in the leg, from which he had suffered for twelve years, and which often prevented him from walking. The Hindoo and Chinese inhabitants of the country, and even those of them who are still pagans, are so accustomed to these cures that they look upon the oil as a sovereign and universal remedy. ${ }^{63}$

When the Hindu pilgrimage was made into the "Coolie Fête," the Hindu faithful started to donate half a bottle of oil and considered the rest efficacious for curing their sicknesses; the donated oil came to be delivered to Catholic pilgrims on the feast day. The Catholic faithful believed in the oil's curative potency because it reached them via the Madonna from Hindu devotees, who attached faith to the remaining oil in the same bottle. ${ }^{64}$ The "La Divina Oil" now flowed through enforced religious boundaries, sustaining the reciprocity of distinct spiritualities and the community of faith centering on La Divin/Sipari Mai. Only by so doing could the oil continue to prove effective for "sickness."

What first brought Hindus to the Madonna in the Catholic church in Siparia for supplication remains an open question. In the late nineteenth century, when they set about creating orthodox Hinduism, Brahmin pundits and acharyas, mostly of northern Indian origin, took advantage of the "articulated discourses" of race and religion to assert the authenticity and virtuousness of their faith. At the same time, they also applied an Indian-origin societal taxonomy based on the stereotype that associated the relatively darker complexion of the Madrasis with lower castes (Cothonay 1893:394; Wood 1968:140) in order to demonstrate the superiority of their religious expression over those of southern Indian origin. As a result, the practices and pantheons, although essential for addressing lay Hindus' day-to-day experience of "sickness," were

63 Thou Shalt Not Bear False Witness Against Thy Neighbor, Dominicana: A Journal of Catholic Literature 3(2) 1902:19o.

64 As part of their devotional worship, Hindu and other pilgrims pour half a bottle of oil into drums placed alongside of the Madonna. By the late 1980s, Catholic pilgrims were collecting the curative oil directly from the drums on the feast day. By the early 2ooos, the church in Siparia was putting donated oil into small plastic bottles and handing them out to Catholic pilgrims. The bottled oil is now on sale in the church's bookstore. 
excluded from the emerging Hindu orthodoxy and orthopraxy. As Brahmin religious leaders came to control access to the means and agents of empowerment, Hindu rituals grew abstract and were intended as extroverted political statements against Christian stigmatization and hegemonic assimilationism. Transformed into La Divin/Sipari Mai, a shared matrix for diverse maternal/female divine manifestations, the Madonna at Siparia became an agent for the Hindu laity, who lacked means of salvation due to their multilayered marginality, to reconnect with the latescent divinity and restore "illegitimate" devotional practices for curing sickness without diluting their religious identity. La Divin/Sipari Mai never forced the faithful to transgress religious boundaries, but instead administered to their medico-religious needs, traveling across the boundaries or arising simultaneously on different sides of the boundaries as distinct, divine selves.

This article has carefully followed the trajectory of the lives and relations of the two statues of La Divina Pastora in Trinidad and demonstrated that they are a tangible indication of the intricate ecclesiastical history of this former British West Indian colony. The conflicts over the power and grace of this Marian image constantly caused tensions and contradictions between the authoritative, patriarchal making of religious orthodoxy and the subaltern, popular praxis of faith. The ascendancy of La Divin/Sipari Mai over the official La Divina Pastora represents the creative faculty of these tensions and contradictions, which defy interpretive control and can be comprehended only by detailed historical research and its reconciliation with ethnography.

\section{Acknowledgement}

The research for this article was supported by the Japan Society for the Promotion of Science's Grant-in-Aid, a postdoctoral fellowship from Saint Louis University, and, not least, parish priest Fr. Martin Sirju and the parishioners of Siparia, Trinidad.

\section{References}

Alcaraz, Fermin de, 1831. La Divina Pastora, ó sea, el Rebaño del buen pastor Jesucristo, guiado, custodiado, y apacentado por su divina Madre María Santísima. Madrid: Imprenta de D. Leonardo Nuñez.

Allsop, Richard, 1996. Dictionary of Caribbean English Usage. Oxford: Oxford University Press. 
Anthony, Michael, 2001. Towns and Villages of Trinidad and Tobago: With Maps of Towns and Important Villages. St. James, Trinidad: Circle Press.

Berger, Peter L., 1967. Sacred Canopy: Elements of a Sociological Theory of Religion. New York: Doubleday.

Bissessarsingh, Angelo, 2012. La Divina Pastora or Siparee-Ke-Mai: Patron Saint and Murti. Unpublished conference paper for Inheritance, Innovation and Continuity5o Years of Indian-T\&T Relations at University of the West Indies, Saint Augustine, Trinidad, August 18.

Boodoo, Gerald, 1993. The "La Divina Pastora/Suparee Ke Mai" Devotions of Trinidad. International Review of Mission 82:383-9o.

Boodoo, Gerald, 20oo. The Faith of the People: The Divina Pastora Devotions of Trinidad. In H. Gossai \& N. Samuel Murrell (eds.), Religion, Culture, and Tradition in the Caribbean. New York: St. Martin's Press, pp. 65-72.

Borde, Pierre-Gustave-Louis, 1982. The History of Trinidad under the Spanish Government, 1622-1797. St. Anns, Trinidad: Paria Publishing Co.

Bowen, Noel P., B.G. Montserin \& Trinidad \& Tobago Population Census Div., 1948. Colony of Trinidad and Tobago Census Album. Port-of-Spain: Government Print Office.

Carrocera, Buenaventura de, 1968. Misión de los Capuchinos en Cumaná: Su Historia, t. I. Caracas: Academia Nacional de la Historia.

Casey, S.P., 1950. Centenary of the Archdiocese of Port-of-Spain-Trinidad, B.W.I., 18501950. Port-of-Spain: Commission for Arrangements of Centenary Observance.

Chauharjasingh, Archibald S., 1982. Lopinot in History: The Story of Lopinot. Arima, Trinidad: Columbus Publishers.

Clark, Henry James, 1892. Census of the Colony of Trinidad, 1891. Port-of-Spain: Government Printing Office.

Collens, James H., 1888. A Guide to Trinidad: A Handbook for the Use of Tourists and Visitors. London: Elliot Stock.

Cothonay, Marie-Bertrand, 1887. Fête de La Divina Pastora a Port-d'Espagne. Les missions Catholique: Bulletin hebdomadaire illustré de l'ouvre de la propagation de la foi 19:167-8. [Comuniquée par le R.P. François Balme, du même ordre, ancien missionnaire à la Trinidad.]

Cothonay, Marie-Bertrand, 1893. Trinidad: Journal d'un Missionnaire Dominicain des Antilles Anglaises. Paris: Victor Retaux et Fils, Libraires-éditeurs.

Cothonay, Marie-Bertrand, 1894. Trinidad. The Rosary Magazine, 2 parts. I, 3 (July):11626 \& II, 4 (August):154-62.

Coyne, C.P., 1950. The Dominicans in Trinidad and Tobago. In S.P. Casey (ed.), Centenary of the Archdiocese of Port-of-Spain-Trinidad, B.W.I., 1850-1950. Port-of-Spain: Commission for Arrangements of Centenary Observance, pp. 19-21.

Day, Charles Williams, 1852. Five Years in the West Indies. 2 vols. London: Colburn \& Co. 
De Verteuil, Louis A., 1858. Trinidad: Its Geography, Natural Resources, Administration, Present Condition, and Prospects. London: Cassell \& Co.

De Verteuil, Louis A., 1884. Trinidad: Its Geography, Natural Resources, Administration, Present Condition, and Prospects. 2nd ed. London: Cassell \& Co.

De Verteuil, Anthony, 200o. Great Estates of Trinidad. Port-of-Spain: Litho Press.

Drane, Augusta T., 1857. The Life of St. Dominic, with a Sketch of the Dominican Order. London: Oxford University Press.

Fox, Richard J., 1982. Rediscovering Fatima. Huntington IN: Our Sunday Visitor.

Goldwasser, Michelle A., 1996. The Rainbow Madonna of Trinidad: A Study in the Dynamics of Belief in Trinidadian Religious Life. PhD Dissertation, University of California, Los Angeles.

Guillet, Marie-Joseph, 1926. Les Dominicains Français à l'ile de la Trinidad (1864-1895). Paris: M. Cattier.

Heim, Maria, 2004. Theories of the Gift in South Asia: Hindu, Buddhist, and Jain Reflections on Dana. New York: Routledge.

Hoetink, Harry, 1967. The Two Variants in Caribbean Race Relations: A Contribution to the Sociology of Segmented Societies. London: Oxford University Press. [Published for the Institute of Race Relations.]

Joseph, Edward L., 1970. History of Trinidad. London: Frank Cass \& Co. [Reprint of edition originally published by A.K. Newman \& Co., 1838.]

Khan, Aisha, 2004. Callaloo Nation: Metaphors of Race and Religious Identity among South Asians in Trinidad. Durham NC: Duke University Press.

Korom, Frank J., 2012. Hosay Trinidad: Muharram Performances in an Indo-Caribbean Diaspora. Philadelphia: University of Pennsylvania Press.

La Divina Pastora Roman Catholic Church, 1965. Consecration of the Church of La Divina Pastora, Siparia by the Most Rev. Dr Finbar Ryan, O.P., D.D. [Unpublished church brochure.]

Lee-Sing, J.C., 1950. Benedictines in the Archdiocese. In S.P. Casey (ed.), Centenary of the Archdiocese of Port-of-Spain-Trinidad, B.W.I., 1850-1950. Port-of-Spain: Commission for Arrangements of Centenary Observance, p. 38.

Look-Lai, Walton, 1993. Indentured Labor, Caribbean Sugar: Chinese and Indian Migrants to the British West Indies, 1838-1918. Baltimore MD: Johns Hopkins University Press.

Mahabir, Kumar, 2007. Mother Kali as Virgin Mary: A New World Hindu-Catholic Phenomenon in Trinidad. South Asian Look: An Independent E-monthly Journal (July). http://www.southasianoutlook.com/issues/2007/july/hindus_convert_a_church_ in_the_caribbean.html (accessed October 14, 2019).

Malinowski, Bronislaw K., 1945. The Dynamics of Culture Change: An Inquiry into Race Relations in Africa. New Haven CT: Yale University Press.

Massé, Armand, 1988. The Diaries of Abbé Armand Massé, 1878-1883. 4 vols. Port-ofSpain: Script J Printers. 
Maunder, Chris, 2016. Our Lady of the Nations: Apparitions of Mary in Twentieth-Century Catholic Europe. Oxford: Oxford University Press.

McNeal, Keith, 2013. Firepass Ceremony. In P. Taylor et al. (eds.), The Encyclopedia of Caribbean Religions, vol. I, pp. 285-89. Champaign: University of Illinois Press.

Michaels, Axel, 2004. Hinduism: Past and Present. Princeton NJ: Princeton University Press.

Mintz, Sydney W. \& Richard Price, 1976. An Anthropological Approach to the AfroAmerican Past: A Caribbean Perspective. Philadelphia PA: Institute for the Study of Human Issues.

Morton, Sarah E., 1916. John Morton of Trinidad:Journals, Letters, and Papers. Toronto: Westminster.

Noel, Theresa, 1984. La Divina Pastora: The Spirit of Siparia. [Church brochure.]

Noel, Theresa, 1995. A Short History of La Divina Pastora Parish, Siparia. [Church brochure.]

Poirier, R.C., 1841. Letter from the Rev. Mr. Poirier, Missionary-Apostolic, to the Right Rev. Dr. Mac Donnell, Bishop of Olympus. Annals of the Propagation of the Faith $3(4): 319-24$.

Procope, Judith, 1980. A Historical Survey of Boissiere Village, No. 1, Maraval, With Particular Reference to the Year 1917. Honours Thesis in Caribbean Studies, University of the West Indies, Saint Augustine, Trinidad.

Rétout, Marie-Thérèse, 1976. Parish Beat: A Historical, Spiritual, and Cultural Account of the Roman Catholic Church's Life in Trinidad and Tobago through Its Parishes. Portof-Spain: Inprint Caribbean.

Rézeau, Dominique \& Pierre, 1995. De la Vendée au Carä̈bes: Le Journal (1878-1884) d'Armand Massé, Missionnaire Apostolique, 2 vols. Paris: Éditions L' Harmattan.

Ryan, Finber, 1939. Our Lady of Fatima, with a Foreword by His Grace Most Reverend John Pius Dowling, O.P. Archbishop of Port-of-Spain. Dublin: Browne \& Nolan Ltd., The Richview Press.

Sanderson Commission, 1909. Report of Committee on Emigration from India to the Crown Colonies and Protectorates. London: His Majesty's Stationary Office.

Schaff, Philip, 1867. The Rise and Progress of Mariolatry. The Contemporary Review 4 (January-April):473-87.

Simmel, Georg, 1955. Conflict: The Web of Group-Affiliations, transl. K.H. Wolff and R. Bendix. New York: Free Press.

Stoler, Ann Laura, 1989. Rethinking Colonial Categories: European Communities and the Boundaries of Rule. Comparative Studies in Society and History 31(1):134-61.

Tierney, Mark, \& Filip Vandenbussche, 2012. Longing to Belong: The Life of Dom Mayeul de Caigny (1862-1939). Port-of-Spain: Paria Publishing.

Trinidad. Registrar-General's Dept., 1923. Census of the Colony of Trinidad, 1921. Port-ofSpain: Government Printing Office. 
Williams, Brackette F., 1991. Stains on My Name, War in My Veins: Guyana and the Politics of Cultural Struggle. Durham NC: Duke University Press.

Winer, Lisa, 2009. Dictionary of the English/Creole of Trinidad \& Tobago: On Historical Principles. Montreal: McGill-Queen's Press.

Wolf, Eric R. \& Sydel Silverman, 2001. Pathways of Power: Building an Anthropology of the Modern World. Berkeley: University of California Press.

Wood, Donald, 1968. Trinidad in Transition: The Years after Slavery. New York: Oxford University Press. 